\title{
MODELS FOR ENERGY EFFICIENCY IMPROVEMENT BY USING MOBILE TECHNOLOGIES AND INTERNET OF THINGS
}

\author{
Igor Bimbiloski, Aleksandar Risteski \\ Faculty of Electrical Engineering and Information Technologies, \\ "Ss. Cyril and Methodius" University in Skopje, \\ Rugjer Bošković bb, P.O. box 574, 1001 Skopje, Republic of Macedonia \\ igor.bimbiloski@gmail.com
}

\begin{abstract}
A b s t r a c t: As the telecom industry is looking for new opportunities to improve its commercial potential by introduction 5G technology, energy industry is rising as potential area for deployment of smart Internet of Things (IoT) solutions and information and communication technology (ICT). Following the recent achievements in digitalization of energy industry, smart phones and mobile application, smart metering, data analytics and artificial intelligence popularity, as well as the human decision-making and behavior based on purely rational choice, we are proposing the consumer centric model for energy efficiency. The model is considering the current communication network features, Wi-Fi and 4G/5G networks and a possibility to influence the consumer behavior in residential segment (households) and achieve reasonable energy savings. Following this model adapted to the Macedonian energy and telecom market specifics, we are estimating that the investment risk versus the potential energy reduction is worth to be further considered by deployment of the proposed system architecture.
\end{abstract}

Key words: energy efficiency; telecom networks; 5G; Wi-Fi; Internet of things; smart phones; software solutions

\section{МОДЕЛ ЗА ПОДОБРУВАҢЕ НА ЕНЕРГЕТСКАТА ЕФИКАСНОСТ СО УПОТРЕБА НА МОБИЛНИ ТЕХНОЛОГІИ НА ИНТЕРНЕТ НА НЕШТА}

А п с т р а к т: Телекомуникациската индустрија бара нови можности за подобрување на комерцијалните перформанси преку промовирање на 5Г-технологијата, при што енергетската индустрија е област со растечки потенцијал за имплементација на паметни решенија базирани на интернет на нешта (ІоТ) и информациски и комуникациски технологии (ИКТ). Следејќи ги моменталните достигнувања во дигитализацијата на енергетската индустрија, паметните телефони и мобилните апликации, паметните мерни уреди, анализата на податоци и популарноста на вештачката интелигенција, како и човечкото однесување и одлучување базирано на рационален избор, предлагаме кориснички ориентиран модел за енергетска ефикасност. Моделот ги зема предвид постојните карактеристики на комуникаските мрежи, мрежите Wi-Fi и 4G/5G и можноста да се влијае на корисничкото однесување во резиденцијалниот сегмент и да се постигнат разумни заштеди на енергија. Ако овој модел се примени на условите на македонскиот енергетски и телекомуникациски пазар, цениме дека инвестициониот ризик наспроти потенцијалот за енергетска заштеда заслужува внимание и размислување за идна имплементација на предложената системска архитектура.

Клучни зборови: енергетска ефикасност; телекомуникациски мрежи; 5Г; Wi-Fi; интернет на нешта; паметни телефони; софтверски решенија 


\section{INTRODUCTION}

Telecom industry is coming to the saturation level of traditional services, like mobile voice and data services, and it is looking to extend its operations in other service areas. This is mostly the reason to drive towards $5 \mathrm{G}$ technology implementation, where except the increase of speed and bandwidth, it will offer two other fields of operation: IoT and massive machine communication and ultra-reliability for critical machine communication [1]. As it is presented in Figure 1, 5G should offer to the end customers i) an unlimited experience in broadband, ii) instant action and iii) service for everything.

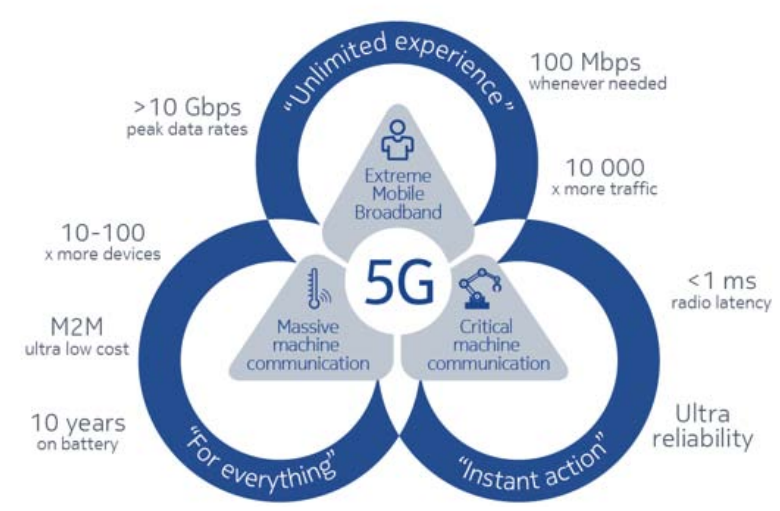

Fig. 1. 5G architecture: A system of systems

$5 \mathrm{G}$ ambition is to cover all types of communications including machine type usage and must therefore be very flexible and also support completely new business models. In 5G, verticals like energy, manufacturing, healthcare and automotive are envisioned as the new user spaces, enabling new applications, markets and businesses.

From the economic aspects, traditional theory postulates that human decision-making and behavior are based on purely rational choice, that people have rational preferences among outcomes, always strive to maximize utility, and act independently based on full and relevant information. Based on these assumptions, traditional economic models predict that people will make decisions that yield the optimal result given budget constraints, and that behavioral choices can be improved by providing people with more information (i.e. by increasing knowledge/awareness) and/or more options (i.e. by increasing choices) [2]

The retail energy use [3] is characterized by a wide range of decision types and contexts, as well as psychological and contextual influences on be- havior. Decision models from different research traditions are all relevant to some aspect of residential energy use. Decision models can inform the design of interventions to change behavior by identifying the key influences on decision making. Each of the research traditions offers specific lessons for intervention design [4]-[7].

Understanding and changing household energy consumption behavior are considered as effective ways to improve energy efficiency and promote energy conservation. With the increasing penetration of conventional and emerging information and communication technologies (ICTs) in energy sector, traditional energy systems are being digitized. The energy big data provides a new way to analyze and understand individuals' energy consumption behavior, and thus to improve energy efficiency and promote energy conservation [8].

Smart meters have been deployed in many countries across the world since early 2000s. The smart meter as a key element for the smart grid is expected to provide economic, social and environmental benefits for multiple stakeholders. There has been much debate over the real values of smart meters. One of the key factors that will determine the success of smart meters is smart meter data analytics, which deals with data acquisition, transmission, processing, and interpretation that bring benefits to all stakeholders [9].

Artificial intelligence is also frequently used about early prediction of building cooling load and heating load and can help engineers design energyefficient buildings [10]. AI-based approach uses historical data to predict future energy use under constraints. Owing to the ease of use and adaptability to seek optimal solutions in a rapid manner, the AI-based approach has gained popularity in recent years [11].

Considering above mentioned developments in telecom network industry, the ICT usage in energy efficiency, smart meters deployment and big data availability, artificial intelligence popularity, but also the importance of consumer behavior and decision making process of the consumer, in this paper we are proposing consumer centric model using smart phones and AI, changing the consumer behavior over electricity consumption. We will present the model that uses network technologies for input data for geolocation, and the smart phones applications for consumer communication. The predictions about the applicability of the model is also presented and the estimated benefits of energy savings. 


\section{BACKGROUND}

In order to find the appropriate model for energy efficiency and explain the reasons behind proposed model, on the beginning of this paper we will consider a few approaches about IoT technologies deployment in energy efficiency applications, 5G applicability in energy use cases, the Wi-Fi use for consumer positioning and coexistence with 5G, and we will propose consumer centric model based on smart phones usage and artificial neural networks, and its influence over consumer behavior.

\section{Energy efficiency approaches}

There are many approaches for ICT deployment in the energy industry [12]. Which model will be used is a question of preference of the user - consumer, whether it is a residential or business user, and the final goal of deployment as it is explained in Figure 2. The IoT techniques, applicable for energy efficiency approaches, are:
- Software based IoT techniques, where one important part are the smart phones. Smart phones, having strong sensing power, are a driving force in the technology industry especially in the emerging IoT domain, using data logging, prediction models and resource behavior analysis, recording data in different applications, contexts, locations and time to predict the energy consumption in smart phones;

- Hardware based IoT techniques, using smart devices with embedded sensors and processing power;

- Policy based techniques, practice by the policy makers and regulators;

- Awareness based techniques, mostly influenced by the relevant stakeholders in energy industry towards the consumer population;

- Changing habits towards green energy;

- Recycling rules for protection of environment green IoT.

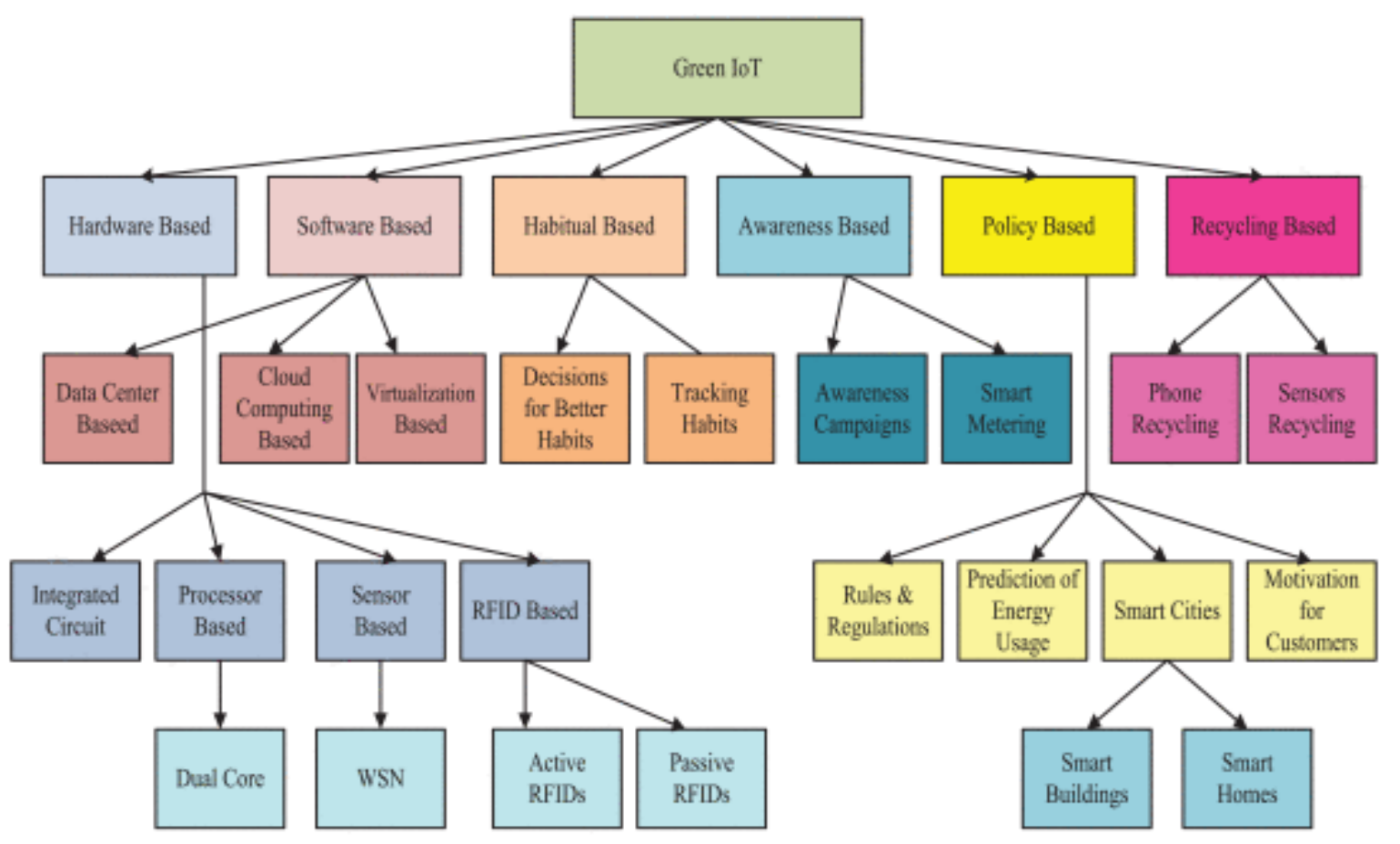

Fig. 2. Taxonomy of green energy IoT techniques

\section{IoT and $5 G$ applicability in energy use cases}

Current telecom networks (2G, 3G, 4G-LTE) are the usual communication solutions for smart solution deployment in energy industry. They are standardized and reliable, and a good base to count on $5 \mathrm{G}$ as even more adequate technology for further use, improved by several functionalities critical for use in energy industry. One of the important expectations from 5G is its security and reliability for monitoring and control of the smart grid, considering it as a critical operation for Dis- 
tribution System Operators (DSOs) with very low risk for outage. In this manner, smart meters are devices with signific- ant role in the communication activities, which will use 5G services for communication, storage, processing and control of operations of the network. Additional role of the smart metering and smart grid is given by new models of localized production of renewable energy, where the control and balance of the energy in the network is becoming more complex [13].

As it is shown in Figure 3, role of the 5G and IoT solutions could be oriented in few segments of the smart grid:

- Generation of the energy - IoT solutions with high reliability and low latency networks are of significant importance to monitor and control global production of power plants (e.g. nuclear), cross-border interconnection, local generation and plants (e.g. Macedonia), renewable generation (e.g. solar, wind, biomass...).

- Transmission and distribution - IoT solutions for grid automation, intelligent stations, smart switches and distribution automation, as well as ICT systems for remote control, condition monitoring and wide-area monitoring.

- Commercial and industrial - smart building with distributed generation of solar energy, distributed energy management system, energy storage and control, Electronic Vehicle Chargers (EVC) system in car park.

Residential - cmart meter with advanced metering infrastructure, energy storage, home automation, smart appliances.

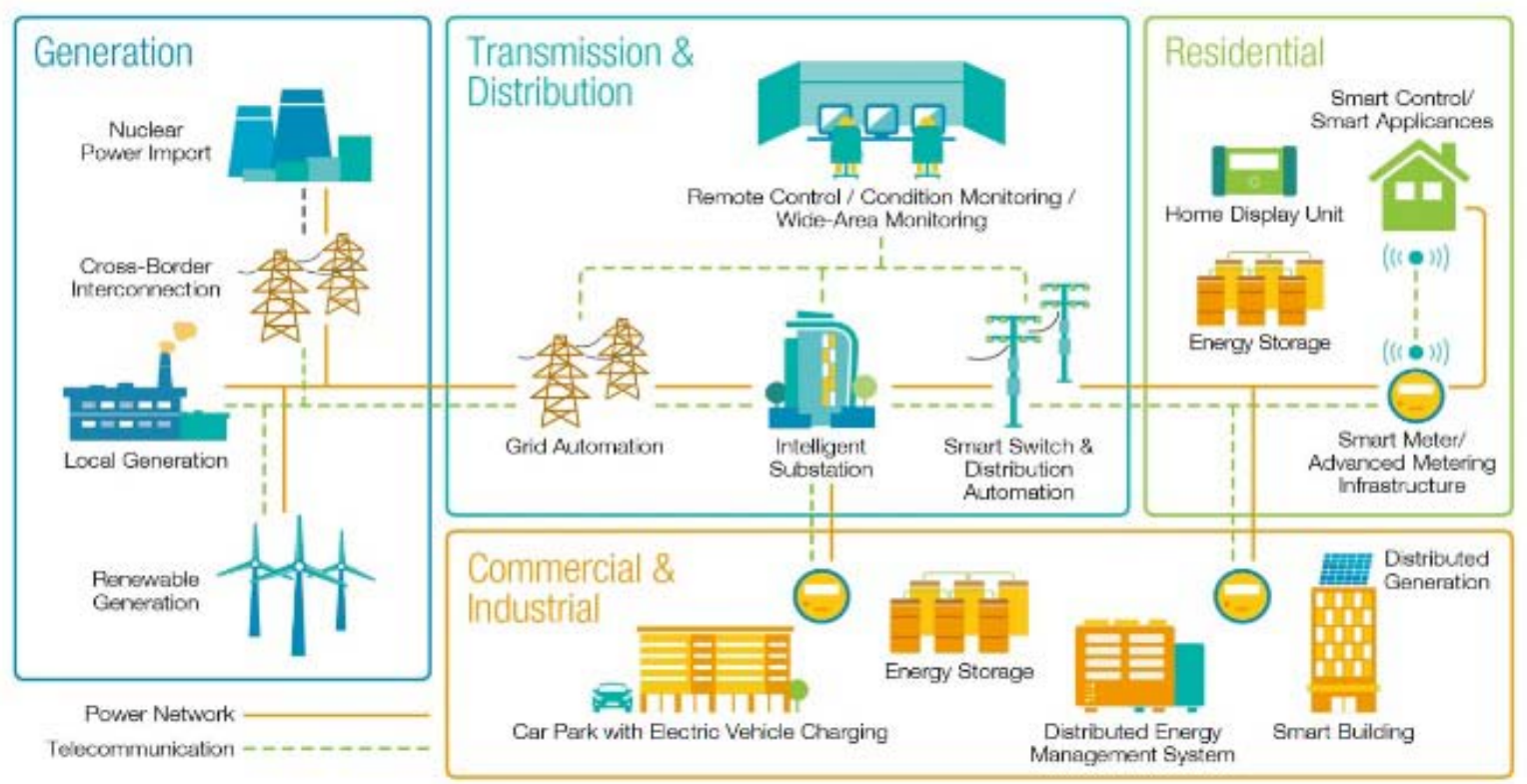

Fig. 3. Smart grid

Basic idea of the model

In this paper we will consider the last two segments of the energy ecosystems, related to residential and business energy efficiency, because these are the segment that could be influenced by consumer behavior. According to the latest statistic in EU countries [14], 52\% of the energy consumption is related with residential and business segment, more that $34 \%$ is on the transport segment and the rest is for other services. A model that is considered in this paper is characterized with three modes of consumer stage: private mode (at home) - C1, working mode (at work) - C2, and moving mode - C3, as it it is shown in Figure 4.

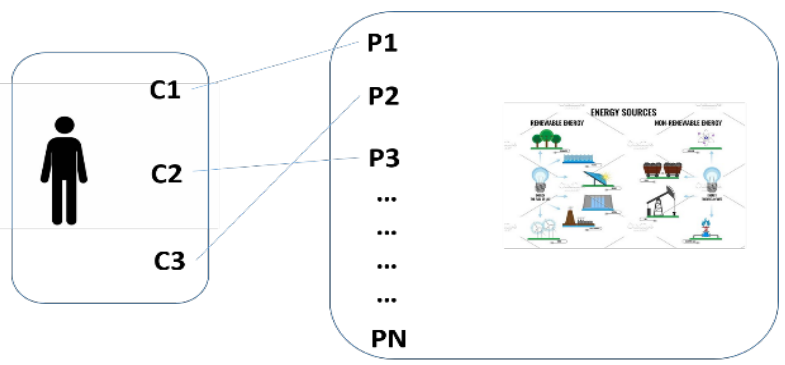

Fig. 4. Three modes of consumer stage: moving, private (home) and business (office) 
The providers of the electricity are shown on the right side of the Figure 4, represented and measured as P1 to PN in real time. Starting from the assumption that energy consumption and provisioning are equal on both sides, we can calculate the total power as:

$$
\sum_{\substack{x=1 \\ y=1}}^{N} P_{x\left(\mathrm{C}_{y}\right)}=P_{\text {total }}=\sum_{x=1}^{M} P_{x} .
$$

The idea of the model is to identify the mode of the consumer (a) and location (b), to measure the electricity consumption is each of the stages (c), to predict further activities with artificial neural networks and to influence consumer behavior via mobile application [15].

a) Mode of the consumer in real time:

$$
C_{x\left(\mathrm{t}_{\mathrm{a}}\right)}=C_{1} \text { or } C_{2} \text { or } C_{3} \text {. }
$$

b) Location of the consumer - provider of the electricity:

$$
P_{x}=f\left(C_{1} \text {, geolocation }\right) .
$$

c) Volume of electricity used by consumer:

$$
P_{x\left(C_{y}\right)}=f\left\{C_{y} \text {, time }\right\} .
$$

In this model we will consider software based IoT techniques, awareness and changing habits techniques. Also, 5G and Wi-Fi networks coexistence will be used as the tools for identification of the consumer position/mode, having in mind that the Wi-Fi is the technology mostly used in residential and business environment.

\section{Coexistence of $5 G$ and Wi-Fi technology for energy efficiency solutions}

The very ambitious goals of 5G are difficult to be achieved as a standalone solution for IoT including here the energy efficiency solutions. Even more, considering that 5G community is still developing the standards for IoT and on the other side capital investment that should bring $5 \mathrm{G}$ in life. So, in the first stage of further development of smart solutions, in the cases related to smart home and smart buildings, the role of the Wi-Fi will be primary.

There are few segments of coexistence of these two technologies. One reason is the capacity of the network throughput, where 5G and Wi-Fi could share the unlicensed spectrum. Even in current 4G-LTE cases, there is a spectrum sharing in order to offload the traffic from LTE to Wi-Fi network, and in some cases it goes up to $50 \%$ traffic offload. This case is relevant for the stationary users in home and office, knowing that most of the time Wi-Fi is preferred over LTE because of the cost of services.

Also, it is almost necessary for $5 \mathrm{G}$ to use the unlicensed spectrum because of the flexibility and the economy. Flexibility in a manner of openness to include as many devices as possible in a short time and with no barriers on number and data volume transmission, and from economy aspect to use unlicensed spectrum with no spectrum fee to decrease the cost of deployment of new IoT solutions.

For the model that we are offering as a concept for energy efficiency, the network preference is explained in the Table 1.

Table 1

Network preference for consumer mode detection

\begin{tabular}{|c|c|c|}
\hline Mode & Wi-Fi & 5G \\
\hline Home (private) & Preferred & Back-up \\
\hline Office (working) & Preferred & Back-up \\
\hline \hline Moving mode (transport) & & Preferred \\
\hline
\end{tabular}

Actually, the Wi-Fi network will be used to identify the home and office location/mode, and use it for further processing with artificial neural networks.

\section{Wi-Fi location positioning in home and office}

There are few methods for positioning of the smart phone in Wi-Fi environment. Cell of origin (COO) is a mobile positioning method for locating a mobile device, which relies on the fact that cellular networks can identify the approximate position of a mobile handset, e.g. in which cell the device is at a given time. The accuracy of this method depends on the size of the cells of the network. The primary advantage of this technique is easy implementation since it does not require complex algorithms, which makes position estimation very fast [16].

Trilateration, uses the distances of an object from three known points, which are usually fixed points with known coordinates to determine the position of an object. This method has been widely used in conventional surveying and GPS positioning [17]. 
The fingerprinting technique has been used for indoor positioning for several years. Its main advantage is that it can use existing WLAN infrastructures or other network environments. It is relatively simple to be deployed. If there are no specific hardware requirements at the mobile device, any existing WLAN infrastructure can be used for positioning.

As the demand for indoor location based services (LBS) is increasing, indoor positioning, one of the key techniques for indoor LBS development has been hot research topic. However, a general solution for indoor positioning has not been discovered, yet. In our model we will use COO method as a positioning method.

\section{Consumer behavior at home and office}

The energy efficiency is influenced by the used technology and by the consumer behavior. As we have seen, the use of technology at home and in the office is highly depending on ICT tools and smart solutions. In the same time, it should be covered by investment in new systems - smart home systems in the home. The other approach with less investment is changing the consumer behavior with existing ICT tools that are available at homes and offices. Mostly, these are communication network represented by Wi-Fi technology and smart phones, highly penetrated over $70 \%$ in the consumer residential usage.

Behavior is a combination of many factors (Figure 5), related by the technology which is available at home, like appliances in home, but also it depends on social elements of the consumers: hab- its, emotions, normative factors. Usually, energy consumption behavior is depending of daily habits and routines (like usage of lights, heating, cooling, cooking...) which are repetitive, and less on the actions which are one-shot behavior (like investment in home energy insulation).

There are many researches on energy efficiency behavior which shows that habits can be changed by building awareness on energy consumption, and to encourage households to reduce consumption $5-15 \%$. The main driver in changing this behavior is saving money, as a direct benefit. Even in the deployment of the smart home solutions, energy efficiency is the second strongest driver to purchase (with 68\%) after safety and security (with 75\%) [18].

Intervention measures such as feedback on consumption via energy bill or energy display (e.g. smart phone) should be clearly presented and consisting of simple messages, relevant to the household savings. It should also contain a kind of goals or commitments, and be consistent and frequent.

There are experimental researches [19] which are estimating which behavior measures can achieve most, long term energy savings: with display units at home, parameters to be measured, location of units, smart meters, better billing models, frequency of billing, historical data, renewable sources, goal settings and commitments, etc.

In the model that we are proposing, all of these factors will be included by using smart phone devices, as a tool for identification of the status of the consumer and in the same time as a display for consumer guidance.

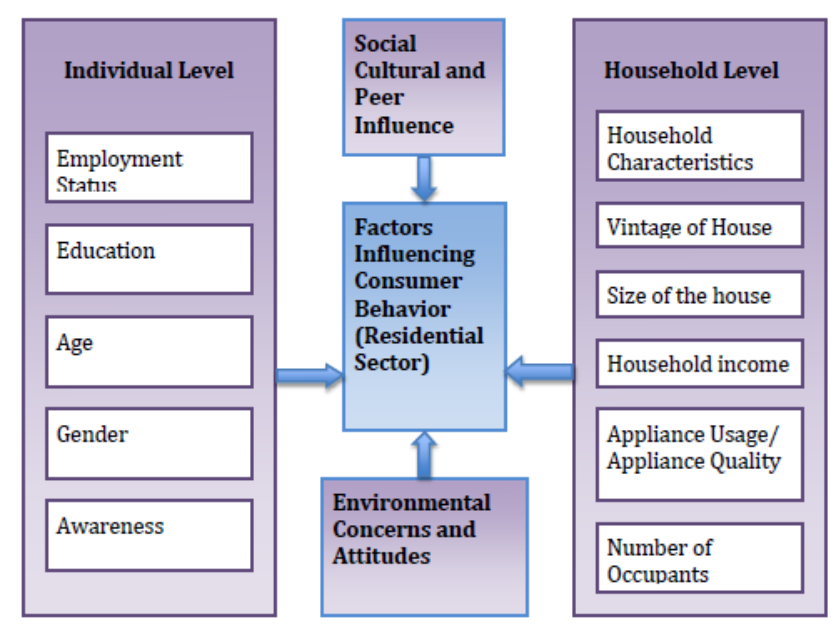

Fig. 5. Factors affecting consummer behaviour (residential) 


\section{SYSTEM ARCHITECTURE}

There are several elements of the architecture for the proposed model, presented in Figure 6 . Within the smart home environment, the network which will be used is the existing Wi-Fi network, and will consolidate the data from all smart devices.

The second element is the smart phone, which is in the permanent communication on IP level via the Wi-Fi network. The smart phone is the element which is defining the mode/stage of the consumer, in this case the home mode. The third element is the back-end system, where the data is stored and processed with artificial neural network (artificial intelligence - AI). Following the processing rules, this server is communicating via the $4 \mathrm{G} / 5 \mathrm{G}$ network to the consumer (smart phone) or to the home devices on any IoT platform.

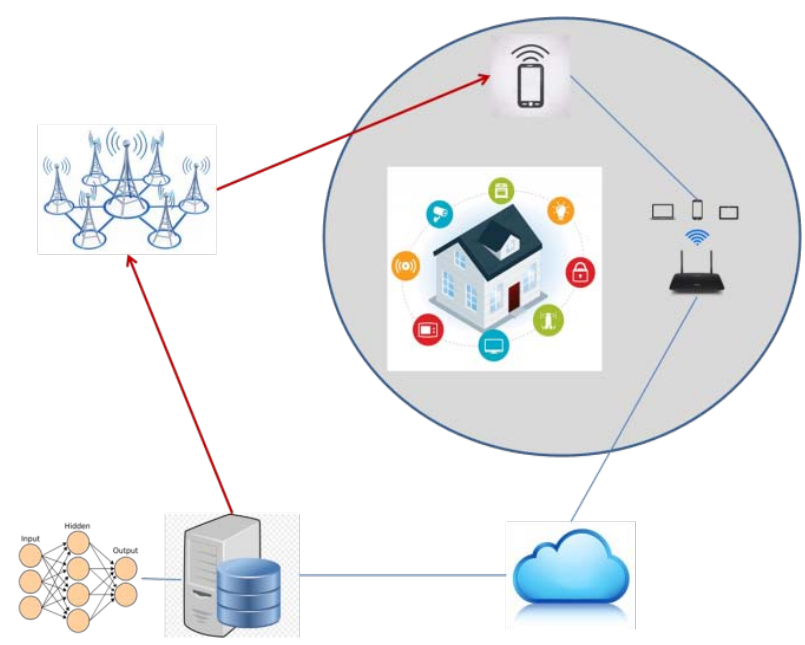

Fig. 6. System architecture

These modules in the systems could be developed independently, and the system is scalable. It means that in the basic level of developments, the provider of the electricity could use the smart phones and mobile application to influence the consumer behavior. The next level of deployment could be individual measurement of the consumption of electricity on home level, by deployment of smart meters, which will improve the quality of data for analysis. Independently, on the later phase the AI modules could be developed and used for automatic management of electricity consumption.

Depending on the movements of the consumer, the smart phone changes the network access from Wi-Fi to $4 \mathrm{G} / 5 \mathrm{G}$ and vice versa, as it is explaining in flow chart on Figure 7. If it is in the 5G network, then it is obvious that the consumer is in moving mode. If it is under Wi-Fi coverage, the consumer is either at home or at work. In that case, there is an electricity consumption measurement available with smart metering devices, and the change in the electricity consumption is registered.

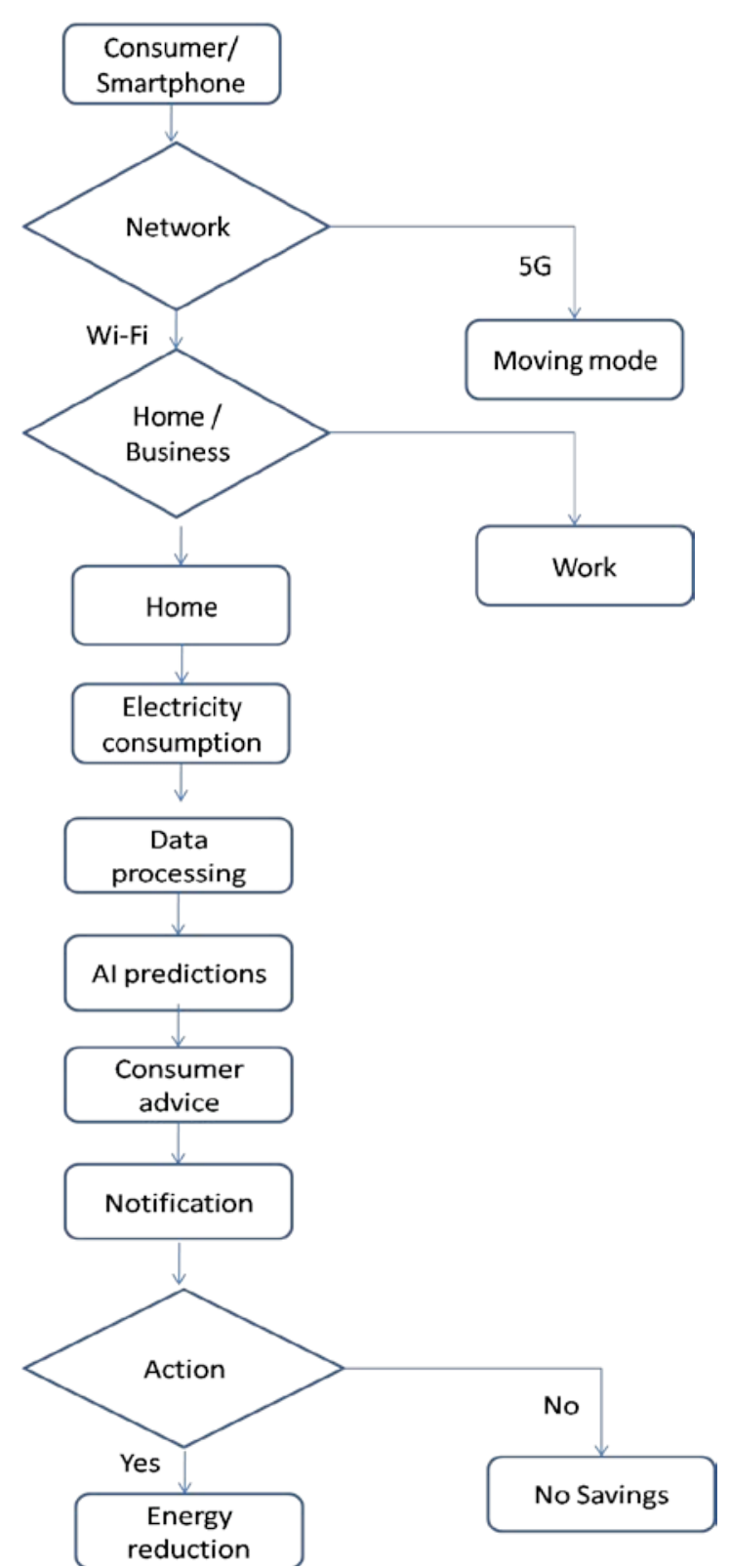

Fig. 7. Flow chart

The information is registered, storage and processed, compared with the historical data of home consumption with artificial neural networks, and prediction for further behavior of consumer is identified. Furthermore, if there is a need to change of the electricity consumption, the system generates notifications towards the consumer, expecting to take an action. 


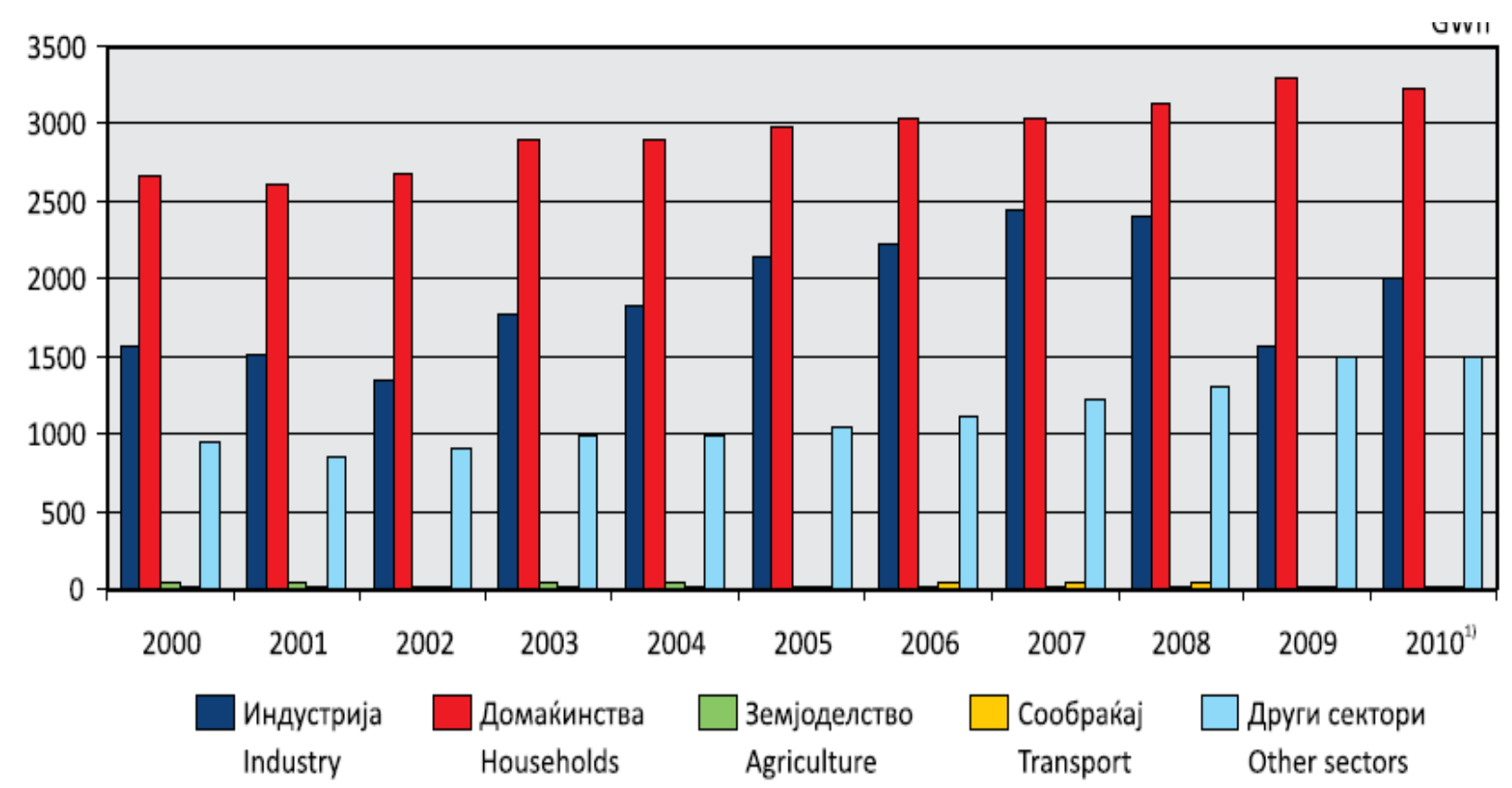

Fig. 8. Final electricity consumption by sectors (Preliminary data)

\section{MACEDONIAN USE CASE AND SAVING POTENTIALS}

In Macedonian case, saving of electricity in residential segment could contribute the most of overall energy efficiency. According to the Macedonian Statistic Office [20] residential segment in Macedonia is consuming more than $3.000 \mathrm{GWh}$ per year, almost $50 \%$ of the total energy consumption of the country. This is higher rate of residential consumption compared to EU where residential segments participate with approximately $30-35 \%$. This shows that in Macedonian case, the proposed model will have more effects considering its consumer centric logic.

The gross national electricity consumption per capita is approximately $4.200 \mathrm{kWh}$, and the final electricity consumption in household per capita is app. $1.600 \mathrm{kWh}$ [20]. In the same time, Macedonia is among the countries with the lowest electricity price in Europe. According to the Eurostat analysis, electricity prices in Macedonia are by $55 \%$ lower than the European average [21]. Having in mind that the average is 3.6 inhabitants/household, the total electricity expenses per household annually are approximately 450 EUR.

One dilemma which needs to be analyzed in the future works is the percentage of consumers which will use the model, i.e. mobile application and act accordingly to the energy efficiency initiatives. If we compare the consumer behavior in similar processes for actionable insights of the consumers, like for example in the retail sales and e-commerce statistics, it shows that $15 \%$ of the consumers are lead to the purchase intention. In our case for energy savings, where we are discussion about the opposite operation (instead of buying we are discussing about the savings for the household budget) we assume that the conversion rate for actionable inside of the consumers could reach the same or higher level of 15\% [22] [23].

Considering that our model is using mobile application as the communication tool with the consumer, and having in mind that penetration of the smart phones in Macedonia is 60\% [24], the average level of penetration of the utility mobile application could go over 200.000 [25]. With this number, the actionable intention of $15 \%$ as it was explained in previous paragraph, will trigger the actions in almost 30.000 household for saving of electricity. It is approximately $5 \%$ of the total 564.000 households in Macedonia [26].

If we follow the benchmarking from the previous projects related to the influence of consumer behavior on electricity efficiency [27] the expected effect is within range of 5-20\% savings per households, or the average of $12 \%$ savings. If we calculate this $12 \%$ saving on $5 \%$ households, the total savings in household lead to $0.6 \%$ savings, or 1.5 million EUR in total national saving.

On the other side, if we calculate the cost of the deployment of the model according to the sys- 
tem architecture in the previous chapter, it could be deployed for less than 50.000 EUR (approximately 10.000 EUR for dual-server, 20.000 EUR for the software development and 10.000 for internet and cloud services, and 10.000 EUR for marketing cost).

It shows that the investment in such model is highly financially beneficial, with very low risk on return of investment and high potential for further operational improvements.

\section{CONCLUSION AND FUTURE WORK}

One of the main drivers of any application for energy efficiency is to be accepted by the main stakeholders of the energy ecosystem and to include financial benefits. In the proposed model, both prerequisites are fulfilled: first, we are using smart phone penetration and its influence over consumer behavior as a wave to trigger energy efficiency actions on consumer side, as second, the expected financial benefits of energy savings are high above the forecasted investment.

The model is using software based platform with embedded artificial intelligence, and $\mathrm{Wi}-\mathrm{Fi}$ and $4 \mathrm{G} / 5 \mathrm{G}$ networks for identification of the consumer behavior. It also considers smart meters deployment on the electricity provider side, which is regular obligation for DSOs on EU market.

Deployment of this model on Macedonian market shows that there is a reasonable potential for savings compared to the initial investment. All of the assumptions of the proposed system are almost fulfilled, with some consideration on the smart meters deployment and the integration in the communication platform of DSO. But, if this assumption is not fulfilled, there should be considered alternative scenarios on household side (like smart home devices) that could replace this requirement.

Future works will be focused on deployment of this system in Macedonian market and analysis of the effects over household savings, to confirm the estimated savings of energy. It will include development of the SW and mobile application, deployment of the system and building awareness of use of application.

\section{REFERENCES}

[1] Nokia networks for Business - https://networks. nokia. com $/ 5$ g/get-ready
[2] Frederiks, E. R., Stenner, Karen, Hobman, E. V.: Household energy use: Applying behavioral economics to understand consumer decision-making and behavior, Renewable and Sustainable Energy Reviews, Vol. 41, pp. 1385-1394 (January 2015).

[3] Wilson, C., Dowlatabadi, H.: Models of Decision Making and Residential Energy Use, Annual Review of Environment and Resources, Vol. 32, pp. 169-203 (November 2007).

[4] Ramos, A., Gago, A., Labandeira, X., Linares, P.: The role of information for energy efficiency in the residential sector, Energy Economics, Vol. 52, Supp. 1, pp. S17-S29 (December 2015).

[5] Newell, R. G., Siikamäki, J.: Nudging Energy Efficiency Behavior: The Role of Information Labels, Journal of the Association of Environmental and Resource Economists, Vol. 1, Num. 4 (December 2014).

[6] Bocvarov, A., Ruskov, P., Ilieva, M.: Consumer behavior change pattern for energy efficiency, Published in: Proceeding EuroPLoP '15 Proceedings of the 20th European Conference on Pattern Languages of Programs, Kaufbeuren, Germany, July 08-12, 2015, Article No. 4.

[7] Frederiks, E. R., Stenner, K., Hobman, E. V.: The SocioDemographic and Psychological Predictors of Residential Energy Consumption: A Comprehensive Review, Energies, 8 (1), 573-609 (2015), https://doi.org/10.3390/ en8010573

[8] Zhou, K., Yang, S.: Understanding household energy consumption behavior: The contribution of energy big data analytics, Renewable and Sustainable Energy Reviews, Vol. 56, pp. 810-819 (April 2016).

[9] Alahakoon, D., Yu, X.: Smart Electricity Meter Data Intelligence for Future Energy Systems: A Survey, IEEE, Transactions on Industrial Informatics, 12 (1), 1-1 (January 2015). DOI: 10.1109/TII.2015.2414355

[10] Chou, J.-S., Bui, D.-K.: Modeling heating and cooling loads by artificial intelligence for energy-efficient building design, Energy and Buildings, Vol. 82, pp. 437-446 (October 2014).

[11] Wang, W., Srinivasan, R. S.: A review of artificial intelligence based building energy use prediction: Contrasting the capabilities of single and ensemble prediction models, Renewable and Sustainable Energy Reviews, Vol. 75, pp. 796-808 (August 2017).

[12] Arshad, R., Zahoor, S., Shah, M. A., Wahid, A,, Yu, H.: Green IoT: An Investigation on Energy Saving Practices for 2020 and Beyond, IEEE Access, vol. 5, pp. 1566715681, 2017. doi: 10.1109/ACCESS.2017.2686092

[13] https://www.clp.com.hk/en/about-clp/power-transmissio n-and-distribution/smart-grid

[14] Bertoldi P., Diluiso F., Castellazzi L., Labanca N., Serrenho T.: Energy Consumption and Energy Efficiency Trends in the EU-28 2000-2015, Publications Office of the European Union, 2018.

[15] Bimbiloski, I., Risteski, A.: Draft Concept for Energy Efficiency Improvement with Smart Phones and Artificial Neural Networks Usage, ETAI 2018, Struga, Macedonia.

[16] Hu, Bin: Wi-Fi Based Indoor Positioning System Using Smartphones, Master thesis, School of Mathematical and Geospatial Sciences College of Science, Engineering and Health, 2013. 
[17] Yim, Jaegeol: A Review of indoor positioning, Advanced Science and Technology Letters Vol. 112 (Architecture and Civil Engineering), pp. 46-49, 2015

[18] Holden, Mary Ellen: New Scripps Networks Study Reveals Smart Living Starts with the Smart Kitchen, 2017, https://www. mediavillage.com/article/new-scripps-studyreveals-smart -living-starts-with-the-smart-kitchen/

[19] Paul, A., Subbiah, R., Marathe, A., Marathe, M.,: A Review of Electricity Consumption Behavior, Consortium for building energy innovations Report, 2012.

[20] N. N., Macedonia in figures - Energy statistics 20002010, Republic of Macedonia, State Statistical Office, 2012.

[21] N. N.: Macedonia among countries with the lowest electricity price in Europe, 2016. http://balkanenergy.com/macedonia-among-countrieswith-the-lowest-electricity-price-in-europe-macedonia28-june-2016/

[22] Dave Chafey: Smart insides, Ecommerce conversion rates - how do yours compare?, 2018, https://www.smartinsights.com /ecommerce/ecommerceanalytics/ecommerce-conversion -rates/

[23] Ayat Shukairu: Mobile App Push Notifications Impact Statistics and Trends, 2018.

https://www.invespcro.com/blog/push-notifications/

[24] N. N,: Share of individuals accessing the internet via mobile devices in Macedonia in 2016 by device, Statista, , 2018.

https://www.statista.com/statistics/712682/mobileinternet-usage-by-device-in-macedonia/

[25] N. N.: App Download and Usage Statistics (2018), http://www.businessofapps.com/data/app-statistics/

[26] N.N. Census of Population, Households and Dwellings in the Republic of Macedonia, 2002, Republic of Macedonia, State Statistical Office, 2004

[27] Martiskainen, Mari: Affecting consumer behavior on energy demand, Final report to EdF Energy, Sussex Energy Group SPRU - Science and Technology Policy Research University of Sussex, 2007. 